\title{
Effect of a hypoglycaemic agent M\&B 39890A on glucagon secretion in isolated rat islets of Langerhans
}

\author{
M. Tadayyon ${ }^{1}$, I. Green ${ }^{1}$, D. Cook $^{2}$ and J. Pratt ${ }^{2}$ \\ ${ }^{1}$ Biochemistry Laboratory, School of Biological Sciences, University of Sussex, Brighton, Sussex and \\ ${ }^{2}$ Research Institute, May \& Baker Ltd., Dagenham, Essex, UK
}

Summary. Administration of the compound M\&B 39890A lowered serum glucose levels significantly $(p<0.001)$ in genetically obese mice, while no effect on serum insulin levels was observed. In in vitro experiments with isolated rat islets of Langerhans M\&B 39890A inhibited arginine-stimulated glucagon release at all concentrations tested $(0.5,5.0$ and $50 \mu \mathrm{mol} / \mathrm{l})$. Insulin secretion was not inhibited by M\&B $39890 \mathrm{~A}(0.5$ and $5.0 \mu \mathrm{mol} / 1)$, but was slightly decreased at $50 \mu \mathrm{mol} / 1$. M\&B 39890A ( $5 \mu \mathrm{mol} / \mathrm{l})$ also inhibited glucagon secretion in vitro in the presence of $2 \mathrm{mmol} / 1,6 \mathrm{mmol} / 1$ and $20 \mathrm{mmol} / \mathrm{l}$ glucose, while exerting no effect on insulin secretion. These results suggest that the hypoglycaemic action of M\&B 39890A may be due to its direct and selective effect on glucagon secretion; this appears to operate by a mechanism different to that of glucose.

Key words: Islets of Langerhans, hypoglycaemia, glucagon release, insulin release, ob/ob mice.
A role for glucagon in the pathogenesis of the obese hyperglycaemic (ob/ob) condition has been suggested [1-3]. One of the agents discovered to reduce hyperglycaemia in the obese mouse was the compound M\&B 39890A, N-(3-imidazol-1-ylpropyl)-2-(3-trifluoromethylbenzenesulphonamido) benzamide hydrochloride. This is a member of a series of novel auto sulphonamido-benzamides found to have hypolipidaemic and hypoglycaemic properties [4]. The purpose of this study was to see if the compound M\&B 39890A was hypoglycaemic in normal rats and to elucidate the mode of action. The endocrine pancreas was chosen for investigation of direct effects of M\&B 39890A, since inhibition of glucagon secretion or stimulation of insulin secretion could explain the observed hypoglycaemic action.

\section{Materials and methods}

\section{In vivo studies in genetically obese mice}

Male obese mice (C57 BL6J ob/ob strain, 46-50 g body weight) from the May \& Baker breeding colony were given M\&B 39890A orally for 3 days over a dose range of $5-200 \mathrm{mg} / \mathrm{kg}$ body weight. Control animals received $0.2 \mathrm{ml}$ vehicle-water. All animals had free access to food throughout the experiments. Mice were killed $3 \mathrm{~h}$ after the third daily dose and bled from the heart. Serum glucose was measured colorimetrically using the G0D-Perid method [5], and serum insulin was radioimmunoassayed using Wellcome insulin binding reagent and insulin standards and iodinated insulin from Amersham International plc.

\section{In vivo glucose tolerance test in normal rats}

Sprague-Dawley male rats (180-200g body weight) from Charles River Ltd. received M\&B 39890A at $100 \mathrm{mg} / \mathrm{kg}$ orally for 3 days. Controls received water alone. Animals were fasted after the second drug dose, and $2.5 \mathrm{~h}$ after the third treatment all animals received an oral load of $2 \mathrm{~g} / \mathrm{kg}\left(\mathrm{D}^{+}\right)$glucose in water. Blood samples were taken from the tail tip for assay of glucose and insulin levels at $30 \mathrm{~min}$ and $2 \mathrm{~h}$ post-glucose loading.

\section{In vitro studies using islets of Langerhans}

Islets of Langerhans were isolated by collagenase digestion of pancreata of Sprague-Dawley rats weighing $200-250 \mathrm{~g}$ [6]. Islets were preincubated for $30 \mathrm{~min}$ at $37^{\circ} \mathrm{C}$ in bicarbonate-buffered medium [7] containing glucose $(20 \mathrm{mmol} / 1)$, Trasylol $(200 \mathrm{KIU} / \mathrm{ml})$, bovine serum albumin $(1 \mathrm{mg} / \mathrm{ml})$ and $\mathrm{CaCl}_{2}(2 \mathrm{mmol} / \mathrm{l})$. Groups of 5 islets were transferred by micropipette to incubation vials containing $0.5 \mathrm{ml} \mathrm{Gey}$ \& Gey buffer [7] with additions of glucose, arginine and M\&B 39890A as described in the Results section. At the end of the incubation period (45 min) samples were withdrawn and frozen for radioimmunoassay of insulin [8] and glucagon [9].

\section{Statistical analysis}

Student's t-test was used for statistical analysis. A $p$ value of $<0.05$ was considered statistically significant.

\section{Results}

Figure 1 illustrates the dose-dependent fall in blood glucose produced by $M \& B 39890 A$ in the obese mouse in 


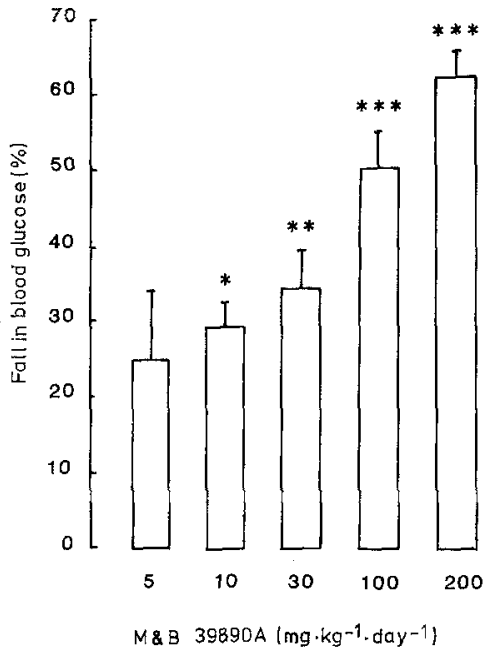

Fig. 1. Obese mice were given different doses of M\&B 39890A orally for 3 days; glucose values are the mean \pm SEM from 6-8 animals. Values significantly different from controls $(* p<0.05, * * p<0.01$, $* * * p<0.001)$
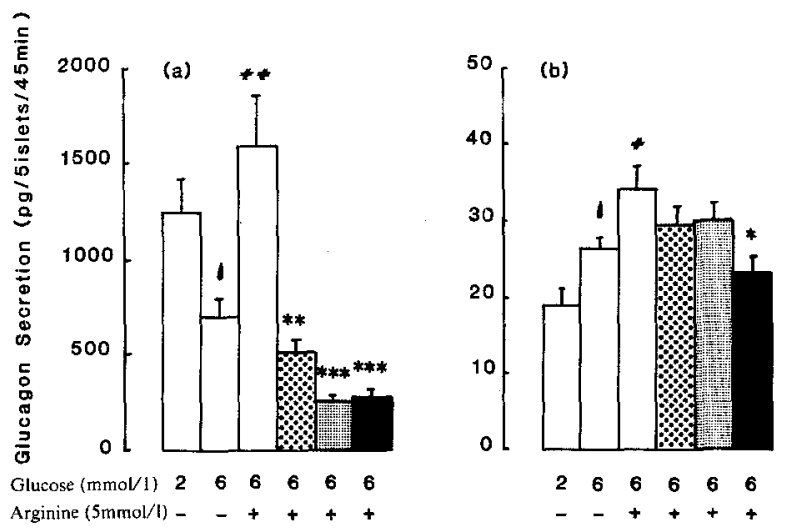

5
5
0
5
5
00
0
0
0
0
0
0
5
0
0
07
$\frac{0}{0}$
0
0
0
0
3
3
3
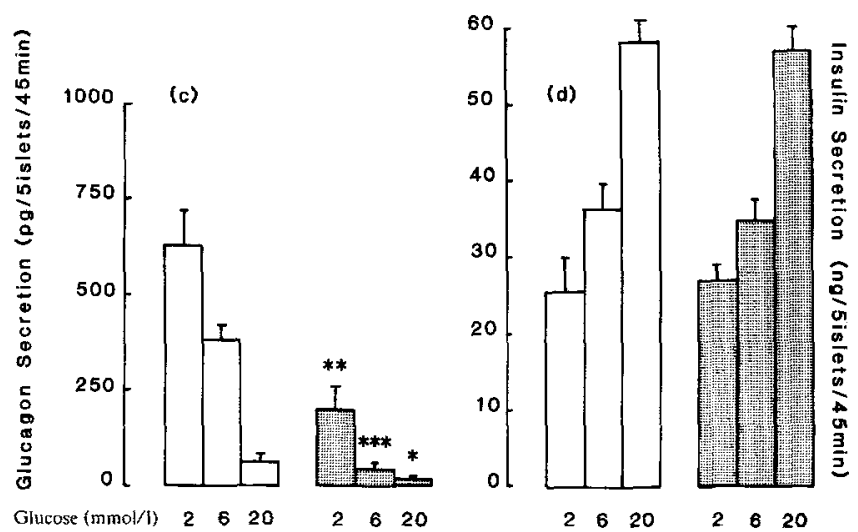

Fig. 2. Effect of 0.5 to $50.0 \mu \mathrm{mol} / 1 \mathrm{M} \& \mathrm{~B} 39890 \mathrm{~A}$ on (a) glucagon and (b) insulin secretion in response to arginine $(5 \mathrm{mmol} / \mathrm{l})$ in isolated rat islets of Langerhans $(n=18)$. Results obtained using $6 \mathrm{mmol} / 1$ glucose were significantly different from those using $2 \mathrm{mmol} / 1$ glucose $(p<$ 0.01 ). Arginine stimulated both insulin and glucagon release significantly $(p<0.01, p<0.005)$. M\&B 39890A reduced arginine-stimulated hormone release significantly $\left({ }^{*} p<0.005, * * p<0.001,{ }^{* * *} p<0.0001\right)$. Panels (c) and (d) illustrate effects of M\&B 39890A ( $5 \mu \mathrm{mol} / \mathrm{l})$ on glucose-induced changes in glucagon and insulin release $(n=10)$. M\&B $39890 \mathrm{~A}$ significantly lowered glucagon secretion in all cases $\left({ }^{*} p<\right.$ $0.05, * * p<0.001, * * * p<0.0001$ ), but had no effect on insulin secretion

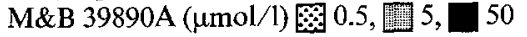

vivo. In a parallel group of obese mice, circulating insulin levels were unaffected by administration of $100 \mathrm{mg}$ / $\mathrm{kg}$ M\&B 39890A (control, 78.6 \pm 4.8 ; treated, $77.2 \pm$ $5.2 \mathrm{ng} / \mathrm{ml} ; n=8)$. The same dose of the compound administered for 3 days to normal rats failed to affect insulin or glucose levels following an oral glucose load. Blood samples taken from the tail tip $30 \mathrm{~min}$ and $2 \mathrm{~h}$ after the glucose load were 9.3 and $5.6 \mathrm{mmol} / 1$ glucose, respectively, for control animals, and 9.4 and $6.4 \mathrm{mmol} / 1$, respectively, for treated animals. Serum insulin measured at $30 \mathrm{~min}$ after the glucose load was also unchanged in the treated animals compared to controls. As expected, increasing glucose concentration from $2 \mathrm{mmol} / 1$ to $6 \mathrm{mmol} / 1$ or $20 \mathrm{mmol} / 1$ led to inhibition of glucagon secretion from the rat islets (Fig. 2a,c) and stimulation of insulin release from these islets (Fig. 2b, d). Arginine stimulated both insulin and glucagon release significantly (Fig. 2a, b) $(p<0.01)$. Incubation of islets in buffer containing arginine $(5 \mathrm{mmol} / \mathrm{l})$ and glucose $(6 \mathrm{mmol} / \mathrm{l})$ with increasing concentrations of M\&B 39890A produced a very significant $(p<0.005)$ dose-related inhibition of glucagon release to $32.5 \%$ of control at $0.5 \mu \mathrm{mol} / 1,16.1 \%$ at $5.0 \mu \mathrm{mol} / 1$ and $16.6 \%$ at $50 \mu \mathrm{mol} / 1$ when compared to groups of islets incubated in medium containing the same concentrations of arginine and glucose. Insulin secretion, on the other hand, was not inhibited when glucagon secretion was suppressed by 0.5 and $5.0 \mu \mathrm{mol} / 1$ concentrations of the compound, although it was slightly decreased by incubation of islets in $50 \mu \mathrm{mol} / 1$ concentrations (Fig. $2 \mathrm{~b}$ ). M\&B 39890A potentiated the inhibitory effect of glucose on glucagon release with significant reductions $(p<0.05-0.0001)$ in glucagon secretion at 2,6 , and $20 \mathrm{mmol} / 1$ medium glucose when compared with the appropriate glucose level $(32 \%, 12 \%$ and $36 \%$ of control, respectively, Fig. $2 \mathrm{c}$ ). In the same experiment the glucose-induced stimulation of insulin release was unaffected by $5 \mu \mathrm{mol} / 1$ M\&B 39890A (Fig. $2 \mathrm{~d}$ ).

\section{Discussion}

Hypoglycaemic agents can act by directly affecting islet hormone secretion, or by affecting glucose handling in peripheral tissues. M\&B 39890A has been shown here to lower blood glucose in genetically obese $(\mathrm{ob} / \mathrm{ob})$ mice without affecting insulin levels (Fig.1). Although the direct or indirect effect of the compound on glucose production or uptake is not known, the results obtained from glucose-loaded normal rats suggest that glucose uptake from the gut into peripheral tissues is unaffected by the compound. It has also been concluded from in vivo experiments in ob/ob mice and rats that $M \& B$ 39890A does not stimulate insulin secretion or potentiate it, and these results were confirmed in our in vitro tests. Induction of a glucagon-deficient state in $\mathrm{ob} / \mathrm{ob}$ mice had been shown to markedly reduce hyperglycaemia in this species [10]. The results obtained in the in 
vitro study indicate that M\&B 39890A could exert its hypoglycaemic effect by inhibiting glucagon release while having no effect on insulin secretion. M\&B 39890A inhibited glucagon secretion in a variety of circumstances, e.g. when glucagon secretion was stimulated by low glucose or arginine-containing media or when glucagon secretion was suppressed with increasing glucose levels in the medium.

Although the mechanism by which M\&B 39890A inhibits glucagon secretion was not investigated, a number of points emerge from the secretion studies. The compound was able to inhibit glucagon secretion over and above potent inhibitory effects of glucose; it may thus act via a different mechanism than that of glucose. Despite the striking effects of the compound on glucagon secretion, insulin secretion was appropriate for the prevailing glucose level, perhaps indicating that $M \& B$ $39890 \mathrm{~A}$ was not having any deleterious effects on islet cell function. It is generally held that there exists an inter-relationship between the release of different islet hormones [11]. Our results show that the previous "priming' of B cells by glucagon sufficed for normal insulin secretion during a 45-min incubation during which glucagon secretion was suppressed by $97 \%$ in comparison with control values.

It is concluded that the hypoglycaemic action of M\&B 39890A may be explained by its potent inhibitory effect on glucagon secretion. Finally, because of its selective effect on glucagon secretion, M\&B 39890A may be a useful tool in the study of islet cell interaction.

Acknowledgments. M.Tadayyon is holder of an Overseas Research Studentship Award. I. Green is the holder of the BDA-Ames senior non-clinical research fellowship.

\section{References}

1. Mayer J, Andrus SB, Silides DJ (1953) Effect of diethyldithiocarbamate and other agents on mice with the obese-hyperglycaemic syndrome. Endocrinology 53:572-581

2. Laube H, Fussganger RD, Pfeiffer EF (1974) Paradoxical glucagon release in obese hyperglycaemic mice. Horm Metab Res 6: 426

3. Flatt PR, Bailey CJ, Buchanan KD (1982) Regulation of plasma immunoreactive glucagon in obese hyperglycaemic (ob/ob) mice. J Endocrinol 95: 215-227

4. Ashton MH, Cook DC, Daniels CJ, Loveless AH, Pratt JD, Bull BT (March 1984) UK Patent Application GB2126225A

5. Werner W, Rey HG, Weilinger H (1970) Properties of a new chromogen for determination of glucose in blood according to the GOD-POD method. Z Anal Chem 252: 224-228

6. Howell SL, Taylor KW (1968) Potassium ions and the secretion of insulin by islets of Langerhans incubated in vitro. Biochem $\mathrm{J} 108$ : $17-24$

7. Gey GO, Gey MK (1936) Maintenance of human normal cells and tumour cells in continuous culture. Am J Cancer 27:45-76

8. Green IC, Perrin D, Pedley K, Leslie RDG, Pyke D (1980) Effects of enkephalins and morphine on insulin release from isolated rat islets. Diabetologia 19:158-161

9. Hii CST, Stutchfield J, Howell SL (1986) Enhancement of glucagon secretion from isolated rat islets of Langerhans by phorbol 12-myristate 13-acetate. Biochem J 233: 287-289

10. Flatt PR, Swanson-Flatt SK, Bailey CJ (1979) Glucagon antiserum: a tool to investigate the role of circulating glucagon in obese hyperglycaemic (ob/ob) mice. Biochem Soc Trans 7: 911-913

11. Pipeleers DG, Schuit FC, Veld PAI, Maes E, Hooghe-Peters EL, Van de Winkel M, Gepts W (1985) Interplay of nutrients and hormones in the regulation of insulin release. Endocrinology 117 : $824-833$

Received: 24 October 1986

and in revised form: 3 December 1986

Dr. I.C.Green

Biochemistry Laboratory

School of Biological Sciences

The University of Sussex

Falmer Brighton BN1 9QG

Sussex

UK 